\title{
Presentamos nueva Sede Web
}
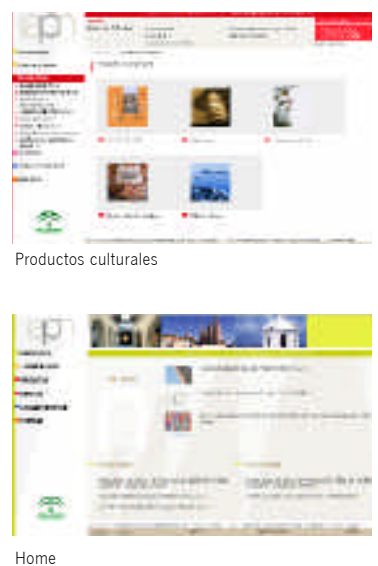

Home

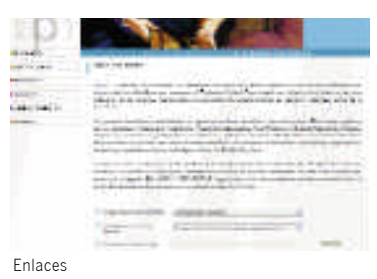

Enlaces
A lo largo de enero de 2006 el IAPH presenta su nueva Sede Web. Durante dos años el IAPH ha trabajado en este ambicioso proyecto con el objetivo de seguir ofreciendo a la sociedad una información sobre el Patrimonio Cultural con valor añadido, bajo una imagen de modernidad y siguiendo los últimos avances en desarrollo web.

En un único espacio virtual a través de los diferentes epigrafes del menú se ofrece al usuario multitud de recursos de información especializados en Patrimonio Cultural, organizados en Canales Temáticos que reproducen las grandes líneas de actuación del IAPH.

El usuario podrá acceder a la información institucional en el apartado ¿Qué es el IAPH? donde aparece la estructura organizativa y funciones de cada uno de los Centros y Departamentos. Del mismo modo se presentan los siguientes Canales Temáticos:

$>$ Canal Temático Cooperación, difunde las últimas líneas de actuación del IAPH en la creación y fomento de acuerdos de colaboración y establecimiento de redes con otras organizaciones para fomentar la investigación científica y tecnológica del Patrimonio Cultural. Especial atención merece el Portal ALCUE, marco de difusión de la red de cooperación ALCUEPatrimonio Cultural destinada a facilitar la cooperación científica y técnica entre Centros de Excelencia de Europa, América Latina y El Caribe en el campo de acción del Patrimonio Cultural.

> Canal Temático Información PH, muestra al usuario la evolución del Patrimonio Cultural en las últimas décadas y tanto los proyectos y colaboraciones como los criterios y metodologías seguidas por el IAPH en el ámbito de la documentación.

$>$ Canal Temático Intervenciones, expone los cri terios metodológicos seguidos en el ámbito de la investigación, restauración y conservación de los bienes culturales a través de destacados proyectos como El Giraldillo, San Telmo o El Salvador.

$>$ Canal Temático Arqueología Subacuática, muestra los últimos avances en investigación, formación, documentación, conservación y difusión del patrimonio sumergido. Un servicio a destacar es el S.O.S, Servicio de Notificación de hallazgos casuales y expolios del Patrimonio Arqueológico Subacuático de Andalucía.

> Canal Temático Formación, ofrece toda la oferta formativa del IAPH así como de otras instituciones culturales nacionales e internacionales a través de un actualizado y completo Calendario de Actividades. $>$ Canal Temático Publicaciones, difunde las últimas publicaciones llevadas a cabo por el IAPH asi como otras que cubren los diferentes aspectos del Patrimonio Cultural.

La nueva Sede Web también ofrece al usuario la posibilidad de consultar la Carta de Servicios del IAPH y acceder a disponer de fichas informativas individuales de cada uno de los cincuenta servicios disponibles.

Asimismo, el IAPH ha desarrollado nuevos productos de información en el marco de su sede web que mues tran aspectos novedosos del Patrimonio Cultural Andaluz. Algunos de ellos son el Catálogo de Intervenciones en el PHA fuente de primer orden para conocer las intervenciones sobre bienes culturales llevadas a cabo en el IAPH con información básica de cada una de ellas Itinerarios y Rutas Culturales, cuyos objetivos se centran en Identificar Itinerarios Culturales según las líneas establecidas por ICOMOS, Documentar Rutas Culturales elaboradas por otras entidades o instituciones, y elaborar nuestras propias rutas según una metodología integradora e interdisciplinar; Información PHA, producto que pretende contextualizar los bienes culturales en el territorio y en la historia a través de información de diferente naturaleza con un acceso geográfico. Junto a estos nuevos productos se han actualizado y desarrollado otros existentes, esto es, el Banco de Imágenes que aumenta el número y calidad de sus imágenes, con información adicional y colecciones temáticas; la Agenda de Formación que permite acceder a la oferta formativa del IAPH y de otras instituciones nacionales e internacionales a través de un directorio temático, y la colección Cuadernos y Cuadernos Técnicos.

El IAPH mantiene el firme compromiso de que el futuro de la gestión del Patrimonio Cultural pasa por la orientación y formación de nuevos profesionales, por ello la nueva Sede Web ofrece al usuario un amplio catálogo de profesiones y titulaciones relacionadas con este ámbito.

Todos estos recursos se ofrecen a través de apli caciones dinámicas e interfaces intuitivas en un esquema de navegación que facilite la comprensión por parte del usuario.

En suma, un paradigma informativo para todos los agentes implicados en la gestión del Patrimonio Cultural.

Caminamos hacia la Administración Electrónica, por ello el IAPH ha fomentado los senvicios interactivos de calidad, se potencian los formularios electrónicos tales como el formulario de suscripción del PH Boletín, formulario de solicitud de información sobre los bienes culturales andaluces o el formulario de suscripción de Cursos.

Se ha trabajado hacia una mejor organización informativa a través de una arquitectura de la información lógica y coherente teniendo como máxi mas la usabilidad y por ende la accesibilidad.

Susana Limón Rodriguez Lorena Ortiz Lozano

Centro de Documentación del IAPH 